\title{
Quantitative Detection of Pear-Pathogenic Stemphylium vesicarium in Orchards
}

\author{
J. Köhl, B. H. Groenenboom-de Haas, P. Kastelein, V. Rossi, and C. Waalwijk
}

First, second, third, and fifth authors: Business unit Biointeractions and Plant Health, Plant Research International, PO Box 69, 6700 AB Wageningen, The Netherlands; and fourth author: Institute of Entomology and Plant Pathology, Sacro Cuore Catholic University, Via Emilia Parmense 84, 29100 Piacenza, Italy.

Accepted for publication 20 July 2009.

\begin{abstract}
Köhl, J., Groenenboom-de Haas, B. H., Kastelein, P., Rossi, V., and Waalwijk, C. 2009. Quantitative detection of pear-pathogenic Stemphylium vesicarium in orchards. Phytopathology 99:1377-1386.

Isolates of Stemphylium vesicarium causing brown spot of pear can be distinguished from nonpathogenic isolates of $S$. vesicarium from pear or from other hosts on the basis of distinctive amplified fragment length polymorphism fingerprinting profiles. DNA fragments specific for isolates pathogenic to pear were identified and a quantitative polymerase chain reaction (PCR) was developed on the sequence from one of these specific DNA loci. This TaqMan PCR has a high sensitivity with a dynamic range for reliable quantification between $1 \mathrm{ng}$ and $100 \mathrm{fg}$ of DNA. The method detected pear-pathogenic isolates of $S$. vesicarium originating from four different European countries and various regions within those countries. No cross-reaction was found with either the

nonpathogenic isolates of S. vesicarium tested or isolates belonging to other Stemphylium spp. or related fungi. The pathogen was detected on leaves with brown-spot symptoms originating from six different locations in The Netherlands, Italy, and Spain. Pear-pathogenic S. vesicarium populations were monitored on crop residues in two Dutch orchards between October 2007 and October 2008. Brown spot had been observed at both orchards at the end of the growing season of 2007. In one location, pearpathogenic $S$. vesicarium was detected only sporadically on crop residues and no brown-spot symptoms were observed on fruit in 2008. At the other location, a pathogenic population was found on fallen pear leaves and on other crop residues but this population decreased during winter. From the beginning of the growing season in 2008 onward, the pathogen population could not be detected and the disease incidence was only $0.6 \%$. The TaqMan PCR will allow more detailed studies on epidemiology of brown spot and on the effect of disease control measures.
\end{abstract}

Stemphylium vesicarium (Wallr.) E. G. Simmons (teleomorph Pleospora herbarum (Pers.) Rabenh.) causes brown spot disease on leaves and fruit of pear $(9,11)$ and leaf diseases on various other crops (e.g., leaf blight on onion [2] and leaf/purple spot on asparagus [5]). The fungus is also able to colonize plant debris (7) which forms a source of inoculum for the next season (11). Because pear fruit with brown-spot symptoms are not marketable, multiple fungicide applications for disease control are common in affected pear orchards to avoid severe losses (11). Brown spot in pear was first observed in the late 1970s in the Po Valley in Italy (17). In the late 1980s, the disease was also found in Spain and France, while the first observations of brown spot in The Netherlands were reported in 1997 and in Belgium in $2002(11,16)$.

Singh et al. (23) found that isolates of $S$. vesicarium pathogenic on pear produced two toxins, SV-toxin I and SV-toxin II. These authors demonstrated that the severity of necrosis correlated with toxin concentration and that pear cultivars with different susceptibility to the pathogen showed different reactions to the toxins. Moreover, they showed that toxicity of these compounds was host specific. Recently, it was shown that isolates of $S$. vesicarium from asparagus and from onion were not pathogenic to pear $(9,15)$. On the other hand, pear-pathogenic isolates but also isolates of S. vesicarium not pathogenic to pear could be isolated from necrotic pear tissue as well as from necrotic grass leaves present in affected orchards (9). Apparently, both pathogenic and nonpathogenic populations of $S$. vesicarium can coexist in pear orchards. Limited information is available on the relationships

Corresponding author: J. Köhl; E-mail address: jurgen.kohl@wur.nl

doi:10.1094/PHYTO-99-12-1377

(c) 2009 The American Phytopathological Society between saprophytic and pathogenic populations of $S$. vesicarium which may compete during colonization of plant debris.

Several studies on the population dynamics of $S$. vesicarium in pear orchards have been performed (e.g., flights of conidia and ascospores of the pathogen have been analyzed to obtain insight in the epidemiology of brown spot and possible control measures) (18). However, spores of pathogenic populations cannot be distinguished from spores of nonpathogenic populations morphologically. Host tissues as well as necrotic tissues of lawn grasses, forbs, and weeds present in pear orchard floors form possible sources of inoculum $(9,19,20)$. The role of such inoculum sources for brown spot epidemics has been studied in field experiments by covering such lawn surfaces with plastic (4) or by treating the orchard floor with antagonists or with urea $(12,14)$. Monitoring of the pear-pathogenic fraction of the total $S$. vesicarium population in potential inoculum sources in orchards is currently only possible by testing individual isolates in laborious bioassays. Hence, there is an urgent need for accurate and robust detection of pearpathogenic $S$. vesicarium populations in orchards.

The objectives of the present study were to (i) develop a molecular tool to discriminate between isolates of $S$. vesicarium pathogenic and nonpathogenic on pear, (ii) develop a method to quantify pear-pathogenic populations of $S$. vesicarium, and (iii) gain insight into the colonization of different substrates present in pear orchards by pear-pathogenic $S$. vesicarium. A method for specific quantification of pear-pathogenic $S$. vesicarium populations will allow tracing of inoculum sources in orchards. This information is essential for the development of sanitation measures for brown-spot prevention. We previously found that fingerprinting isolates pathogenic on pear, isolates nonpathogenic on pear, and isolates originating from either asparagus or onion using amplified fragment length polymorphism (AFLP) showed signifi- 
cant concordance with host plants (9). Isolates pathogenic on pear originating from either pear tissues or from necrotic grass leaves collected in pear orchards clustered together, whereas isolates from onion and from asparagus belonged to separate clusters (9). The approach of this study was to select specific DNA fragments which are present in AFLP fingerprints of pear-pathogenic isolates but absent in nonpathogenic isolates. A quantitative polymerase chain reaction (PCR), based on TaqMan technology, was developed and applied for the specific quantification of pearpathogenic populations of $S$. vesicarium in environmental samples.

\section{MATERIALS AND METHODS}

Fungal isolates. Isolates used in this study were collected from orchards throughout The Netherlands (9), Belgium (from P. Creemers, Pcfruit, Gorsem, Belgium), Italy (15), and Spain (from I. Llorente, Institute of Food and Agricultural Technology, University of Girona) (Table 1). In all, 15 isolates of $S$. vesica- rium coming from The Netherlands were used for marker development; 57 were used for validation of the TaqMan PCR method, together with 9 isolates belonging to other species and genera. All isolates were grown for 4 weeks on potato dextrose agar (PDA) at $18^{\circ} \mathrm{C}$ with $12 \mathrm{~h}$ of blacklight per day.

DNA isolation. Mycelium and spores of cultured isolates were scraped from the agar surface and freeze dried. DNA was extracted using the DNeasy plant mini kit (Qiagen, Westburg, Germany) with the following modifications. Prior to extraction, the fungal mass was mechanically disrupted by bead-beating for $10 \mathrm{~s}$ at 5,000 BPM in a ribolyser (Hybaid, Teddington, UK). The prescribed incubation at $65^{\circ} \mathrm{C}$ in lysis buffer was prolonged from $10 \mathrm{~min}$ to $1 \mathrm{~h}$. The DNA was eluted in two times $50 \mu \mathrm{l}$ of the elution buffer supplied with the extraction kit.

DNA in pulverized field samples was extracted from $15-\mathrm{mg}$ subsamples using the DNeasy 96 plant kit (Qiagen) with the following modifications. Again, the incubation at $65^{\circ} \mathrm{C}$ was prolonged from $10 \mathrm{~min}$ to $1 \mathrm{~h}$. The DNA was eluted in two times $100 \mu \mathrm{l}$ of the elution buffer supplied with the extraction kit.

TABLE 1. Detection of Stemphylium vesicarium isolates by TaqMan polymerase chain reaction (PCR) and their origin

\begin{tabular}{|c|c|c|c|c|c|c|c|}
\hline \multirow[b]{2}{*}{ Isolate $^{\mathrm{a}}$} & \multicolumn{5}{|c|}{ Origin } & \multirow[b]{2}{*}{ Pathogenicity $^{\mathrm{c}}$} & \multirow[b]{2}{*}{$\mathrm{PCR}^{\mathrm{d}}$} \\
\hline & Host & Tissue & Location $^{\mathrm{b}}$ & Latitude/longitude & Year & & \\
\hline \multicolumn{8}{|l|}{ Marker } \\
\hline PRI 854 & Pear cv. Conference & Fruit & Randwijk, NL & $51^{\circ} 57^{\prime} \mathrm{N} / 5^{\circ} 43^{\prime} \mathrm{E}$ & 2003 & $\mathrm{P}+$ & Yes \\
\hline PRI 868b & Pear cv. Conference & Fallen leaf & Randwijk, NL & $51^{\circ} 57^{\prime} \mathrm{N} / 5^{\circ} 43^{\prime} \mathrm{E}$ & 2003 & $\mathrm{P}-$ & No \\
\hline PRI 886 & Pear cv. Conference & Leaf & Randwijk, NL & $51^{\circ} 57^{\prime} \mathrm{N} / 5^{\circ} 43^{\prime} \mathrm{E}$ & 2003 & $\mathrm{P}-$ & No \\
\hline PRI 893 & Pear cv. Conference & Fallen leaf & Rossum, NL & $51^{\circ} 48^{\prime} \mathrm{N} / 5^{\circ} 20^{\prime} \mathrm{E}$ & 2003 & $\mathrm{P}-$ & No \\
\hline PRI 911 & Pear cv. Conference & Fruit & Vianen, NL & $51^{\circ} 59^{\prime} \mathrm{N} / 5^{\circ} 06^{\prime} \mathrm{E}$ & 2003 & $\mathrm{P}-$ & No \\
\hline PRI 933 & Pear cv. Conference & Fruit & Dinteloord, NL & $51^{\circ} 38^{\prime} \mathrm{N} / 4^{\circ} 22^{\prime} \mathrm{E}$ & 2003 & $\mathrm{P}+$ & Yes \\
\hline PRI 875 & Orchard lawn grass & Necrotic leaf & Randwijk, NL & $51^{\circ} 57^{\prime} \mathrm{N} / 5^{\circ} 43^{\prime} \mathrm{E}$ & 2003 & $\mathrm{P}+$ & Yes \\
\hline PRI 938 & Asparagus & Leaf & Maasbree, NL & $51^{\circ} 22^{\prime} \mathrm{N} / 6^{\circ} 03^{\prime} \mathrm{E}$ & 2003 & $\mathrm{P}-$ & No \\
\hline PRI 946 & Asparagus & Leaf & Roggel, NL & $51^{\circ} 16^{\prime} \mathrm{N} / 5^{\circ} 55^{\prime} \mathrm{E}$ & 2003 & $\mathrm{P}-$ & No \\
\hline PRI 955 & Asparagus & Leaf & Ell, NL & $51^{\circ} 13^{\prime} \mathrm{N} / 5^{\circ} 48^{\prime} \mathrm{E}$ & 2003 & $\mathrm{P}-$ & No \\
\hline PRI 958 & Asparagus & Leaf & Limburg, NL & - & 2003 & $\mathrm{P}-$ & No \\
\hline PRI 898 & Onion & Leaf & Rhenen, NL & $51^{\circ} 57^{\prime} \mathrm{N} / 5^{\circ} 34^{\prime} \mathrm{E}$ & 2003 & $\mathrm{P}-$ & No \\
\hline PRI 900 & Onion & Leaf & Marknesse, NL & $52^{\circ} 43^{\prime} \mathrm{N} / 5^{\circ} 52^{\prime} \mathrm{E}$ & 2003 & $\mathrm{P}-$ & No \\
\hline PRI 903 & Onion & Leaf & Westmaas, NL & $51^{\circ} 47^{\prime} \mathrm{N} / 4^{\circ} 28^{\prime} \mathrm{E}$ & 2003 & $\mathrm{P}-$ & No \\
\hline PRI 927 & Onion & Leaf & Nagele, NL & $52^{\circ} 39^{\prime} \mathrm{N} / 5^{\circ} 43^{\prime} \mathrm{E}$ & 2003 & $\mathrm{P}-$ & No \\
\hline \multicolumn{8}{|l|}{ Test } \\
\hline PRI 850 & Pear cv. Conference & Fruit & Leerbroek, NL & $51^{\circ} 54^{\prime} \mathrm{N} / 5^{\circ} 03^{\prime} \mathrm{E}$ & 2003 & $\mathrm{P}+$ & Yes \\
\hline PRI 852 & Pear cv. Conference & Fruit & Krabbendijke, NL & $51^{\circ} 26^{\prime} \mathrm{N} / 4^{\circ} 07^{\prime} \mathrm{E}$ & 2003 & $\mathrm{P}+$ & Yes \\
\hline PRI 854 & Pear cv. Conference & Fruit & Randwijk, NL & $51^{\circ} 57^{\prime} \mathrm{N} / 5^{\circ} 43^{\prime} \mathrm{E}$ & 2003 & $\mathrm{P}+$ & Yes \\
\hline PRI 865ab & Pear cv. Conference & Fallen leaf & Rossum, NL & $51^{\circ} 48^{\prime} \mathrm{N} / 5^{\circ} 20^{\prime} \mathrm{E}$ & 2003 & $\mathrm{P}-$ & No \\
\hline PRI 869 & Pear cv. Conference & Fallen leaf & Rossum, NL & $51^{\circ} 48^{\prime} \mathrm{N} / 5^{\circ} 20^{\prime} \mathrm{E}$ & 2003 & $\mathrm{P}+$ & Yes \\
\hline PRI 890 & Pear cv. Doyenné & Fallen leaf & Velddriel, NL & $51^{\circ} 46^{\prime} \mathrm{N} / 5^{\circ} 18^{\prime} \mathrm{E}$ & 2003 & $\mathrm{P}+$ & Yes \\
\hline PRI 891c & Pear cv. Doyenné & Fallen leaf & Velddriel, NL & $51^{\circ} 46^{\prime} \mathrm{N} / 5^{\circ} 18^{\prime} \mathrm{E}$ & 2003 & $\mathrm{P}+$ & Yes \\
\hline PRI 894 & Pear cv. Doyenné & Fallen leaf & Randwijk, NL & $51^{\circ} 57^{\prime} \mathrm{N} / 5^{\circ} 43^{\prime} \mathrm{E}$ & 2003 & $\mathrm{P}+$ & Yes \\
\hline PRI 915 & Pear cv. Conference & Fruit & 's Gravenpolder, NL & $51^{\circ} 27^{\prime} \mathrm{N} / 3^{\circ} 54^{\prime} \mathrm{E}$ & 2003 & $\mathrm{P}+$ & Yes \\
\hline PRI 918 & Pear cv. Conference & Fruit & Lexmond, NL & $51^{\circ} 58^{\prime} \mathrm{N} / 5^{\circ} 02^{\prime} \mathrm{E}$ & 2003 & $\mathrm{P}+$ & Yes \\
\hline PRI 920 & Pear cv. Conference & Fruit & Numansdorp, NL & $51^{\circ} 44^{\prime} \mathrm{N} / 4^{\circ} 26^{\prime} \mathrm{E}$ & 2003 & $\mathrm{P}+$ & Yes \\
\hline PRI 921 & Pear cv. Conference & Fruit & Schoonrewoerd, NL & $51^{\circ} 55^{\prime} \mathrm{N} / 5^{\circ} 07^{\prime} \mathrm{E}$ & 2003 & $\mathrm{P}+$ & Yes \\
\hline PRI 930 & Pear cv. Conference & Fruit & Schoonrewoerd, NL & $51^{\circ} 55^{\prime} \mathrm{N} / 5^{\circ} 07^{\prime} \mathrm{E}$ & 2003 & $\mathrm{P}+$ & Yes \\
\hline PRI 931 & Pear cv. Conference & Fruit & Schoonrewoerd, NL & $51^{\circ} 55^{\prime} \mathrm{N} / 5^{\circ} 07^{\prime} \mathrm{E}$ & 2003 & $\mathrm{P}+$ & Yes \\
\hline PRI 933 & Pear cv. Conference & Fruit & Dinteloord, NL & $51^{\circ} 38^{\prime} \mathrm{N} / 4^{\circ} 22^{\prime} \mathrm{E}$ & 2003 & $\mathrm{P}+$ & Yes \\
\hline PRI 934 & Pear cv. Conference & Fruit & Vianen, NL & $51^{\circ} 59^{\prime} \mathrm{N} / 5^{\circ} 06^{\prime} \mathrm{E}$ & 2003 & $\mathrm{P}+$ & Yes \\
\hline PCF-KOG $301^{\mathrm{e}}$ & Pear cv. Conference & Fruit & Binderveld, BE & $51^{\circ} 27^{\prime} \mathrm{N} / 6^{\circ} 03^{\prime} \mathrm{E}$ & 2003 & $\mathrm{P}+$ & Yes \\
\hline
\end{tabular}

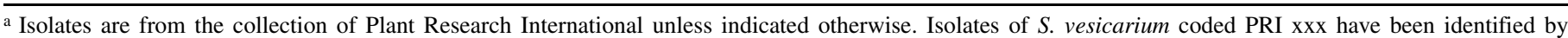
sequence analysis of fragments of EF1, ITS, and GPD genes (9); isolates of Alternaria spp. have been identified according to Simmons (22). Isolates used for marker development (Marker) or test validation (Test).

b NL, The Netherlands; IT, Italy; ES, Spain; BE, Belgium; USA; United States; - = not recorded.

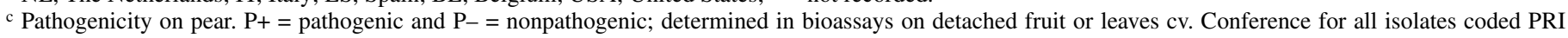
xxx (9); n.d. = not determined.

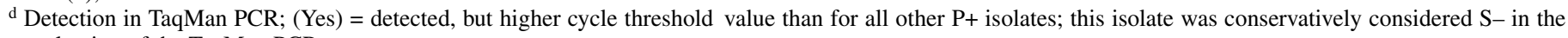
evaluation of the TaqMan PCR.

e Kindly provided by P. Creemers, Pcfruit, Gorsem, Belgium.

f Instituto di Entomologia e Patologia vegetale, Università Cattolica S. Cuore, Piacenza, Italy. Isolates identified according to Simmons (21).

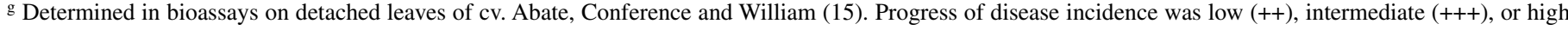
(++++); the ++ isolates (i.e., 440 e\93, 424\93, and 369\00) were conservatively considered P- in the evaluation of the TaqMan PCR (Table 3).

${ }^{\mathrm{h}}$ Kindly provided by I. Llorente, Institute of Food and Agricultural Technology, University of Girona, Girona, Spain.

i Centraalbureau voor Schimmelcultures (CBS).

j Deutsche Sammlung von Mikroorganismen und Zellkulturen GmbH (DSMZ). 
AFLP analyses. To obtain markers for the detection of pathogenic isolates, the AFLP analysis was aimed at finding population-specific fragments and not isolate-specific fragments (i.e., unique fragments present in all pear-pathogenic isolates and absent in the other populations). To speed up this process and to avoid running multiple AFLP gels with single isolates, three individual pear-pathogenic isolates (PRI 854, PRI 875, and PRI 933) were profiled and compared with pools of either isolates nonpathogenic on pear but originating from pear orchards (isolates PRI 886, PRI 893, PRI 911, and PRI 868b), isolates from asparagus (PRI 938, PRI 946, PRI 955, and PRI 958), or isolates from onion (PRI 898, PRI 900, PRI 903, and PRI 927). Each of these DNA preparations was analyzed using 16 primer combinations $(E c o$ RI primer [+C] or [+AG] combined with $\mathrm{Mse}$ I primer $[+\mathrm{ANN}])$.

Restriction and ligation reactions were performed in a single step and, for accurate pipetting, a mastermix was made for all samples. This mix consisted of a multitude of $10 \mu \mathrm{l}$ of $5 \times \mathrm{RL}$ buffer (50 mM Tris, pH 7.5; $50 \mathrm{mM} \mathrm{Mg-acetate;} 250 \mathrm{mM} \mathrm{K}$ acetate; $25 \mathrm{mM}$ dithiothreitol; and bovine serum albumin at $250 \mathrm{ng}$ $\left.\mu \mathrm{l}^{-1}\right), 0.5 \mu \mathrm{l}$ of $\mathrm{Mse} \mathrm{I}$ endonuclease $\left(10 \mathrm{U} \mathrm{l}^{-1}\right.$; New England

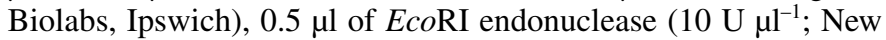
England Biolabs), $2 \mu \mathrm{l}$ of T4 DNA ligase (1 $\mathrm{U} \mathrm{ml}^{-1}$; New England Biolabs), $1 \mu \mathrm{l}$ of MseI adaptor (50 pM; Applied Biosystems, Nieuwerkerk aan de IJssel, The Netherlands), $1 \mu \mathrm{l}$ of EcoRI adaptor (5 pM; Applied Biosystems), and $1 \mu \mathrm{l}$ of ATP (10 mM).

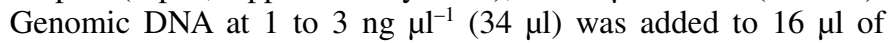
master mix and incubated at $37^{\circ} \mathrm{C}$ for $2 \mathrm{~h}$.

The restriction-ligation samples were diluted by adding $150 \mu \mathrm{l}$ of water, and $5 \mu \mathrm{l}$ of the diluted fragments with ligated adaptors was added to $15 \mu \mathrm{l}$ of reaction mixture consisting of $2 \mu \mathrm{l}$ of $10 \times$ PCR reaction buffer (Eurogentec, Seraing, Belgium), $0.8 \mu \mathrm{l}$ of dNTPs (5 mM each nucleotide), $1.2 \mu \mathrm{l}$ of $\mathrm{MgCl}_{2}$ (25 mM, Euro-

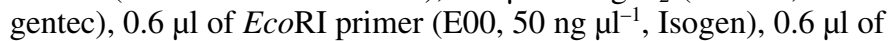

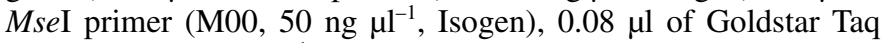
polymerase $\left(5 \mathrm{U} \mu \mathrm{l}^{-1}\right.$, Eurogentec), and $9.7 \mu \mathrm{l}$ of water. The

TABLE 1. (continued from preceding page)

\begin{tabular}{|c|c|c|c|c|c|c|c|}
\hline \multirow[b]{2}{*}{ Isolate $^{\mathrm{a}}$} & \multicolumn{5}{|c|}{ Origin } & \multirow[b]{2}{*}{ Pathogenicity $^{\mathrm{c}}$} & \multirow[b]{2}{*}{ PCR } \\
\hline & Host & Tissue & Location $^{\text {b }}$ & Latitude/longitude & Year & & \\
\hline PCF-KOG $314^{\mathrm{e}}$ & Pear cv. Conference & Fruit & Spalbeek, BE & $50^{\circ} 57^{\prime} \mathrm{N} / 5^{\circ} 14^{\prime} \mathrm{E}$ & 2003 & $\mathrm{P}+$ & Yes \\
\hline PCF-KOG $315^{\mathrm{e}}$ & Pear cv. Conference & Fruit & Limburg, NL & - & 2003 & $\mathrm{P}+$ & (Yes) \\
\hline PCF-KOG $316^{\mathrm{e}}$ & Pear cv. Conference & Fruit & Beveren, BE & $51^{\circ} 13^{\prime} \mathrm{N} / 4^{\circ} 15^{\prime} \mathrm{E}$ & 2003 & $\mathrm{P}+$ & Yes \\
\hline $\mathrm{BR} 11^{\mathrm{f}}$ & Pear cv. Conference & Fruit & Altedo, IT & $44^{\circ} 40^{\prime} \mathrm{N} / 11^{\circ} 29^{\prime} \mathrm{E}$ & 1994 & $\mathrm{P}+(++++)^{\mathrm{g}}$ & Yes \\
\hline $493 \mathrm{~B} \backslash 93^{\mathrm{f}}$ & Pear cv. Abate & Fruit & Viallaparo, IT & $45^{\circ} 09^{\prime} \mathrm{N} / 10^{\circ} 47^{\prime} \mathrm{E}$ & 1993 & $\mathrm{P}+(++++)^{\mathrm{g}}$ & Yes \\
\hline $88 / 6^{\mathrm{f}}$ & Pear cv. Abate & Fruit & Baricella IT & $44^{\circ} 41^{\prime} \mathrm{N} / 11^{\circ} 26^{\prime} \mathrm{E}$ & 1994 & $\mathrm{P}+(+++)^{\mathrm{g}}$ & Yes \\
\hline $97 \backslash 94^{f}$ & Pear cv. Abate & Fruit & Mezzano, IT & $44^{\circ} 27^{\prime} \mathrm{N} / 12^{\circ} 05^{\prime} \mathrm{E}$ & 1994 & $\mathrm{P}+(+++)^{\mathrm{g}}$ & Yes \\
\hline Isa $94 / 1^{\mathrm{f}}$ & Pear cv. Conference & Fruit & Altedo, IT & $44^{\circ} 40^{\prime} \mathrm{N} / 11^{\circ} 29^{\prime} \mathrm{E}$ & 1994 & $\mathrm{P}+(++++)^{\mathrm{g}}$ & Yes \\
\hline 440 el93 f & Pear cv. Abate & Fruit & Porto Maggiore, IT & $44^{\circ} 41^{\prime} \mathrm{N} / 11^{\circ} 49^{\prime} \mathrm{E}$ & 1993 & $\mathrm{P}+(++)^{\mathrm{g}}$ & Yes \\
\hline $450 \mathrm{a} \backslash 93^{\mathrm{f}}$ & Pear cv. Conference & Fruit & Baricella, IT & $44^{\circ} 41^{\prime} \mathrm{N} / 11^{\circ} 26^{\prime} \mathrm{E}$ & 1993 & $\mathrm{P}+(++++)^{\mathrm{g}}$ & Yes \\
\hline $369 \backslash 00^{f}$ & Pear cv. Conference & Fruit & Copparo, IT & $44^{\circ} 58^{\prime} \mathrm{N} / 11^{\circ} 44^{\prime} \mathrm{E}$ & 2000 & $\mathrm{P}+(++)^{\mathrm{g}}$ & Yes \\
\hline $88 / 5^{f}$ & Pear cv. Abate & Fruit & Baricella, IT & $44^{\circ} 41^{\prime} \mathrm{N} / 11^{\circ} 26^{\prime} \mathrm{E}$ & 1994 & $\mathrm{P}+(+++)^{\mathrm{g}}$ & Yes \\
\hline $424 \backslash 93^{\mathrm{f}}$ & Pear cv. Abate & Fruit & Calcara, IT & $44^{\circ} 32^{\prime} \mathrm{N} / 11^{\circ} 07^{\prime} \mathrm{E}$ & 1993 & $\mathrm{P}+(++)^{\mathrm{g}}$ & Yes \\
\hline CL $93^{f}$ & Pear cv. Abate & Fruit & S. Possidonio, IT & $44^{\circ} 54^{\prime} \mathrm{N} / 11^{\circ} 01^{\prime} \mathrm{E}$ & 1993 & $\mathrm{P}+(++++)^{\mathrm{g}}$ & Yes \\
\hline $429 \backslash 93^{\mathrm{f}}$ & Pear cv. Abate & Fruit & Cavezzo, IT & $44^{\circ} 59^{\prime} \mathrm{N} / 11^{\circ} 01^{\prime} \mathrm{E}$ & 1993 & $\mathrm{P}+(++++)^{\mathrm{g}}$ & Yes \\
\hline $173 \mathrm{~A}^{\mathrm{f}}$ & Pear cv. Abate & Fruit & Ferrara, IT & $44^{\circ} 50^{\prime} \mathrm{N} / 11^{\circ} 37^{\prime} \mathrm{E}$ & 2000 & $\mathrm{P}+(++++)^{\mathrm{g}}$ & Yes \\
\hline Isa $94^{\mathrm{f}}$ & Pear cv. Conference & Fruit & Altedo, IT & $44^{\circ} 40^{\prime} \mathrm{N} / 11^{\circ} 29^{\prime} \mathrm{E}$ & 1994 & $\mathrm{P}+(++++)^{\mathrm{g}}$ & Yes \\
\hline Isa $94 / 2^{\mathrm{f}}$ & Pear cv. Conference & Fruit & Altedo, IT & $44^{\circ} 40^{\prime} \mathrm{N} / 11^{\circ} 29^{\prime} \mathrm{E}$ & 1994 & $\mathrm{P}+(++++)^{\mathrm{g}}$ & Yes \\
\hline Sv EPS- $2^{\text {h }}$ & Pear cv. Passe crassane & Fruit & Girona, ES & $41^{\circ} 51^{\prime} \mathrm{N} / 2^{\circ} 51^{\prime} \mathrm{E}$ & 1991 & $\mathrm{P}+$ (low virulence) & Yes \\
\hline Sv EPS-26 ${ }^{\mathrm{h}}$ & Pear cv. Passe crassane & Fruit & Girona, ES & $41^{\circ} 51^{\prime} \mathrm{N} / 2^{\circ} 51^{\prime} \mathrm{E}$ & 1991 & $\mathrm{P}+($ high virulence $)$ & Yes \\
\hline PRI 859 & Orchard lawn grass & Necrotic leaf & Randwijk, NL & $51^{\circ} 57^{\prime} \mathrm{N} / 5^{\circ} 43^{\prime} \mathrm{E}$ & 2003 & $\mathrm{P}+$ & Yes \\
\hline PRI 860 & Orchard lawn grass & Necrotic leaf & Randwijk, NL & $51^{\circ} 57^{\prime} \mathrm{N} / 5^{\circ} 43^{\prime} \mathrm{E}$ & 2003 & $\mathrm{P}+$ & Yes \\
\hline PRI 861 & Orchard lawn grass & Necrotic leaf & Rossum, NL & $51^{\circ} 48^{\prime} \mathrm{N} / 5^{\circ} 20^{\prime} \mathrm{E}$ & 2003 & $\mathrm{P}+$ & Yes \\
\hline PRI 863 & Orchard lawn grass & Necrotic leaf & Randwijk, NL & $51^{\circ} 57^{\prime} \mathrm{N} / 5^{\circ} 43^{\prime} \mathrm{E}$ & 2003 & $\mathrm{P}-$ & No \\
\hline PRI 875 & Orchard lawn grass & Necrotic leaf & Randwijk, NL & $51^{\circ} 57^{\prime} \mathrm{N} / 5^{\circ} 43^{\prime} \mathrm{E}$ & 2003 & $\mathrm{P}+$ & Yes \\
\hline PRI 877 & Orchard lawn grass & Necrotic leaf & Randwijk, NL & $51^{\circ} 57^{\prime} \mathrm{N} / 5^{\circ} 43^{\prime} \mathrm{E}$ & 2003 & $\mathrm{P}-$ & No \\
\hline PRI 878 & Orchard lawn grass & Necrotic leaf & Randwijk, NL & $51^{\circ} 57^{\prime} \mathrm{N} / 5^{\circ} 43^{\prime} \mathrm{E}$ & 2003 & $\mathrm{P}+$ & Yes \\
\hline PRI 882 & Orchard lawn grass & Necrotic leaf & Randwijk, NL & $51^{\circ} 57^{\prime} \mathrm{N} / 5^{\circ} 43^{\prime} \mathrm{E}$ & 2003 & $\mathrm{P}+$ & Yes \\
\hline PRI 94 & Apple & Leaf & Randwijk, NL & $51^{\circ} 57^{\prime} \mathrm{N} / 5^{\circ} 43^{\prime} \mathrm{E}$ & 2003 & $\mathrm{P}-$ & No \\
\hline PRI 102 & Apple & Leaf & Randwijk, NL & $51^{\circ} 57^{\prime} \mathrm{N} / 5^{\circ} 43^{\prime} \mathrm{E}$ & 2003 & $\mathrm{P}-$ & No \\
\hline PRI 135 & Apple & Leaf & Randwijk, NL & $51^{\circ} 57^{\prime} \mathrm{N} / 5^{\circ} 43^{\prime} \mathrm{E}$ & 2003 & $\mathrm{P}-$ & No \\
\hline PRI 940 & Asparagus & Leaf & Limburg, NL & - & 2003 & $\mathrm{P}-$ & No \\
\hline PRI 948 & Asparagus & Leaf & Horst, NL & $51^{\circ} 27^{\prime} \mathrm{N} / 6^{\circ} 03^{\prime} \mathrm{E}$ & 2003 & $\mathrm{P}-$ & No \\
\hline PRI 951 & Asparagus & Leaf & Limburg, NL & - & 2003 & $\mathrm{P}-$ & No \\
\hline $266^{\mathrm{f}}$ & Asparagus & Leaf & Montanaso, IT & $45^{\circ} 40^{\prime} \mathrm{N} / 11^{\circ} 29^{\prime} \mathrm{E}$ & 1992 & $\mathrm{P}-$ & No \\
\hline $249 / 450^{f}$ & Asparagus & Leaf & Montanaso, IT & $45^{\circ} 40^{\prime} \mathrm{N} / 11^{\circ} 29^{\prime} \mathrm{E}$ & 1992 & $\mathrm{P}-$ & No \\
\hline $249 / 449^{f}$ & Asparagus & Leaf & Montanaso, IT & $45^{\circ} 40^{\prime} \mathrm{N} / 11^{\circ} 29^{\prime} \mathrm{E}$ & 1992 & $\mathrm{P}-$ & No \\
\hline PRI 906 & Onion & Leaf & Slootdorp, NL & $52^{\circ} 51^{\prime} \mathrm{N} / 4^{\circ} 58^{\prime} \mathrm{E}$ & 2003 & $\mathrm{P}-$ & No \\
\hline PRI 908 & Onion & Leaf & Munnekenzijl, NL & $53^{\circ} 18^{\prime} \mathrm{N} / 6^{\circ} 16^{\prime} \mathrm{E}$ & 2003 & $\mathrm{P}-$ & No \\
\hline PRI 929 & Onion & Leaf & Lelystad, NL & $52^{\circ} 31^{\prime} \mathrm{N} / 5^{\circ} 29^{\prime} \mathrm{E}$ & 2003 & $\mathrm{P}-$ & No \\
\hline Alternaria brassicicola 177 & Brassica oleracea & Seed & - & - & 1991 & n.d. & No \\
\hline Alternaria alternata 424 & Cauliflower & Seed & Groessen, NL & $51^{\circ} 55^{\prime} \mathrm{N} / 6^{\circ} 03^{\prime} \mathrm{E}$ & 2007 & n.d. & No \\
\hline Alternaria alternata 381 & Brassica oleracea & Seed & Poland & - & 2001 & n.d. & No \\
\hline Cladosporium cladosporioides $\mathrm{H} 39$ & Apple & Leaf & $\mathrm{NL}$ & - & 2004 & n.d. & No \\
\hline Pleospora alfalfae CBS $192.86^{\mathrm{i}}$ & Medicago sativa & Leaf & Western Australia & - & 2004 & n.d. & No \\
\hline \multicolumn{8}{|l|}{ Stemphylium lycopersici } \\
\hline CBS $321.87^{\mathrm{i}}$ & Lycopersicon esculentum & - & Dakar, Senegal & - & - & n.d. & No \\
\hline \multicolumn{8}{|l|}{ S. herbarum type strain } \\
\hline P. tarda CBS $714.68^{\mathrm{i}}$ & Medicago sativa & - & Ontario, Canada & - & - & n.d. & No \\
\hline S. solani CBS $408.54^{\mathrm{i}}$ & Lycopersicon esculentum & - & Charleston, SC, USA & - & - & n.d. & No \\
\hline S. solani DZMS $63045^{\mathrm{j}}$ & Trifolium pratense & Leaf spots & Germany & - & - & n.d. & No \\
\hline
\end{tabular}


preselective PCR program started with an initial incubation at $94^{\circ} \mathrm{C}$ for $120 \mathrm{~s}$; followed by 34 cycles of $94^{\circ} \mathrm{C}$ for $30 \mathrm{~s}, 56^{\circ} \mathrm{C}$ for $30 \mathrm{~s}$, and $72^{\circ} \mathrm{C}$ for $60 \mathrm{~s}$; followed by $10 \mathrm{~min}$ at $72^{\circ} \mathrm{C}$ and cooled to $4^{\circ} \mathrm{C} ; 190 \mu \mathrm{l}$ of water was added to $10 \mu \mathrm{l}$ of preamplification sample.

The EcoRI-primers [+C] or [+AG] were radioactively labeled as follows: $0.1 \mu \mathrm{l}$ of $5 \times \mathrm{T} 4$ forward buffer (Invitrogen), $0.19 \mu \mathrm{l}$ of water, $0.1 \mu \mathrm{l}$ of primer EcoRI primer [+C] or [+AG] $\left(50 \mathrm{ng}^{-1}\right)$, $0.01 \mu \mathrm{l}$ of T4-kinase (10 $\mathrm{U}^{-1} \mathrm{l}^{1}$, Invitrogen), $0.1 \mu \mathrm{l}$ of $\gamma^{3}{ }^{33} \mathrm{P}$-ATP (adenosine $5^{\prime}$ triphosphate; Perkin Elmer, Groningen, The Netherlands), and $1 \mathrm{~h}$ of incubation at $37^{\circ} \mathrm{C}$. Then, $10 \mu \mathrm{l}$ of the diluted nonselective amplification sample was mixed with $10 \mu \mathrm{l}$ of selective PCR mix containing $0.5 \mu$ of radioactive-labeled EcoRI mix, $0.6 \mu \mathrm{l}$ of MseI-primer +[ANN] (Isogen), $0.8 \mu \mathrm{l}$ of dNTP, $2 \mu \mathrm{l}$ of $10 \times$ PCR reaction buffer, $1 \mu \mathrm{l}$ of $\mathrm{MgCl}_{2}, 0.08 \mu \mathrm{l}$ of Goldstar Taq polymerase, and $5 \mu \mathrm{l}$ of water. Different mixes were made using 16 MseI primers + [ANN]. These samples were amplified using the following PCR program: an initial cycle of $94^{\circ} \mathrm{C}$ for $30 \mathrm{~s}$, $65^{\circ} \mathrm{C}$ for $30 \mathrm{~s}$, and $72^{\circ} \mathrm{C}$ for $60 \mathrm{~s}$; followed by 12 touchdown cycles $\left(94^{\circ} \mathrm{C}\right.$ for $30 \mathrm{~s}, 65$ to $56^{\circ} \mathrm{C}$ for $30 \mathrm{~s}$ with the annealing temperature decreasing by $0.7^{\circ} \mathrm{C}$ every cycle, and $72^{\circ} \mathrm{C}$ for $60 \mathrm{~s}$ ); followed by 24 cycles of $94^{\circ} \mathrm{C}$ for $30 \mathrm{~s}, 56^{\circ} \mathrm{C}$ for $30 \mathrm{~s}$, and $72^{\circ} \mathrm{C}$ for $60 \mathrm{~s}$; and finally cooled to $4^{\circ} \mathrm{C}$. Radioactively labeled PCR products $(5 \mu \mathrm{l})$ were separated by polyacrylamide $(6 \%)$ gel electrophoresis. Gel slices corresponding to AFLP bands putatively characteristic for specific pathotypes (e.g., pathogenic or nonpathogenic on pear versus pathogenic on asparagus or onion) were excised from gel and heated for $10 \mathrm{~min}$ at $99^{\circ} \mathrm{C}$ in $100 \mu \mathrm{l}$ of TrisEDTA buffer (10 mM Tris and $0.1 \mathrm{mM}$ EDTA, pH 8.0). The DNA in solution was reamplified using the AFLP primers applied in the fingerprinting: $2 \mu \mathrm{l}$ of DNA, $3 \mu \mathrm{l}$ of $\mathrm{MgCl}_{2}(25 \mathrm{mM}), 2 \mu \mathrm{l}$ of dNTPs $(5 \mathrm{mM}$ each nucleotide $), 1.5 \mu \mathrm{l}$ of $\mathrm{Mse}$ I primer $(10 \mu \mathrm{M})$, $1.5 \mu \mathrm{l}$ of EcoRI primer $(10 \mu \mathrm{M}), 5 \mu \mathrm{l}$ of $10 \times$ PCR buffer, $0.2 \mu \mathrm{l}$ of Goldstar Taq polymerase, and $34.8 \mu$ of water. The PCR protocol started with an initial incubation at $94^{\circ} \mathrm{C}$ for $120 \mathrm{~s}$; followed by 34 cycles of $94^{\circ} \mathrm{C}$ for $30 \mathrm{~s}, 56^{\circ} \mathrm{C}$ for $40 \mathrm{~s}$, and $72^{\circ} \mathrm{C}$ for $60 \mathrm{~s}$; followed by $10 \mathrm{~min}$ at $72^{\circ} \mathrm{C}$. The sequences of the reamplified DNA were determined on an ABI PRISM 3100 capillary automated sequencer according to recommended protocols with the DYEnamic ET Dye Terminator Cycle Sequencing Kit (Amersham Biosciences, Roosendaal, The Netherlands).

TaqMan PCR. Separate PCR reactions were performed to quantify pathogenic $S$. vesicarium and the amplification control (AC). TaqMan PCR reactions were performed in a 96-well format in an ABI PRISM 7500 apparatus, and green fluorescent protein (GFP) served as an amplification control (8). For each $S$. vesicarium TaqMan reaction, a $2-\mu \mathrm{l}$ sample was mixed with $23 \mu \mathrm{l}$ of reaction mix containing $12.5 \mu \mathrm{l}$ of $2 \times$ Premix Ex Taq, $0.4 \mu \mathrm{l}$ of ROX reference Dye (both Takara Bio Inc., Otsu, Japan.), $100 \mathrm{nM}$ FAM-labeled probe, and $320 \mathrm{nM}$ each forward and reverse primer. For each 96-well plate used, a 10-fold serial dilution ranging from $1 \mathrm{ng}$ to $100 \mathrm{fg}$ of the corresponding pathogen DNA (S. vesicarium isolate PRI 933) was run in parallel for reference. The thermal cycling conditions for $S$. vesicarium and AC included an initial $10 \mathrm{~min}$ at $95^{\circ} \mathrm{C}$, followed by 40 cycles. Each cycle consisted of $15 \mathrm{~s}$ at $95^{\circ} \mathrm{C}$ and $60 \mathrm{~s}$ at $60^{\circ} \mathrm{C}$. Measurements obtained for samples which showed suppression of the AC amplification were not included in data analysis but the TaqMan PCR reactions were repeated after 10 -fold dilution of the sample. From the obtained cycle threshold $\left(\mathrm{C}_{\mathrm{t}}\right)$ values of TaqMan PCR for the DNA dilution series and for DNA extracts of plant samples, the concentrations of $S$. vesicarium DNA in the samples were calculated and expressed as picograms of DNA of pear-pathogenic $S$. vesicarium per milligram of plant tissue (dry weight).

Orchards. The amounts of plant residues and pear-pathogenic $S$. vesicarium populations thereon were monitored in two orchards of pear (Pyrus communis) cv. Conference between October 2007 and November 2008. One orchard was planted on river clay in Randwijk $\left(51^{\circ} 57^{\prime} \mathrm{N}, 5^{\circ} 42^{\prime} \mathrm{E}\right)$, central Netherlands, and the other on marine clay in Breskens $\left(51^{\circ} 23^{\prime} \mathrm{N}, 3^{\circ} 33^{\prime} \mathrm{E}\right)$, southwest Netherlands. In the Randwijk orchard, the soil in the tree strip areas was kept bare, whereas tree strips in the Breskens orchard weeds were treated only by a single herbicide application in March. Hence, weeds were present in the tree strips of this orchard during the major part of the sampling period. At both locations, the orchard floor between tree rows was covered with permanent grass sods which were mowed during the growing season. Both orchards had a history of brown spot disease. The overall disease incidence on fruit at harvest time in 2007 was $<1 \%$ in Randwijk and $\approx 25 \%$ in Breskens. Overall brown-spot incidences on leaves were estimated at $<1 \%$ and 5 to $10 \%$, respectively. Management during the sampling period differed considerably between the two orchards. In Randwijk, no fungicide applications for controlling brown spot or other diseases were scheduled. However, after severe hail damage, copper oxychloride, captan, and thiophanate-methyl were applied alone or in combination at four dates between 23 June and 9 July to prevent Nectria cankers. In Breskens, a fungicide program was applied to the canopy to control pear scab (Venturia pirina), fruit tree canker (Nectria galligena), brown spot (S. vesicarium), and various fruit rots. The following fungicides were applied alone or in combinations at 24 dates between 26 February and 1 September: copper oxychloride, hydrogen sulfide, dodine, captan, cyprodinil, thiram, difenoconazole, fludioxonil, trifloxystrobin, boscalid, and pyraclostrobin. In both orchards, no sanitation measures such as leaf shredding or removal of pruned twigs were applied. Grass alleys were mown in Randwijk 11 times between 3 April and 14 October. In Breskens, grass was mown five times between 2 April and 27 August. All grass residues were left in the alleys.

Sampling and sample processing. In Randwijk, two plots were identified, each consisting of a 30-by-1.8-m row of trees and 30 -by-1-m grass strips on either side of the tree row. The distance between the two plots was $2.5 \mathrm{~m}$. The two plots in Breskens each consisted of two rows of trees $(30$ by $1.8 \mathrm{~m})$ and the separating grass alley ( 30 by $1.4 \mathrm{~m}$ ). The distance between the two plots was $12 \mathrm{~m}$. At monthly intervals from the middle of October 2007 until the middle of October 2008, fallen pear leaves and necrotic grass tissues were separately collected in each plot from four random 25-by-25-cm patches in the grass alleys. Fallen necrotic pear leaves and other plant residues (prunings, fruit, and necrotic weed tissues) were also collected separately from four random 25-by$25-\mathrm{cm}$ patches within the tree strips. At the same time, the upper soil layer $(2 \mathrm{~cm})$ of the tree strip areas (after removal of residues from the soil surface) was sampled in each plot at 10 random circled patches $(7 \mathrm{~cm}$ in diameter). Samples from different patches within each plot were pooled per residue type and sample date. In June, August, and October, 10 unaffected leaves and, if present, 10 leaves showing symptoms of brown spot disease also were collected from the trees in each plot.

Samples of six leaves with and six leaves without symptoms of brown spot were collected in summer 2008 in each of four different orchards in Italy (Table 2). Further samples were obtained from an orchard in Girona, Spain and in Randwijk, The Netherlands.

All samples were transported cooled in plastic bags, weighed, and stored within $12 \mathrm{~h}$ at $-18^{\circ} \mathrm{C}$. After storage, each sample was shredded in frozen condition and split into two subsamples. One subsample was dried at $105^{\circ} \mathrm{C}$ to assess the dry matter content. The other subsample was subsequently freeze dried and pulverized in a laboratory mill with a 1-mm mesh sieve. Powdered subsamples were stored at $-18^{\circ} \mathrm{C}$ until DNA extraction. Frozen soil samples were mechanically broken and processed in a hydropneumatic elutriation system similar to that described by Smucker et al. (24) to separate plant material larger than $1.6 \mathrm{~mm}$ from mineral soil particles. After removal of living roots, the plant debris was processed as described above for the other plant residues. 
Data analysis. The TaqMan PCR method was evaluated for sensitivity, specificity, and accuracy in identifying the $S$. vesicarium isolates pathogenic for pear on both fungal colonies and pear leaves by means of the Bayesian analysis (25). The 57 isolates of $S$. vesicarium not used for marker development (Table 1) were considered pathogenic $(\mathrm{P}+)$ or not $(\mathrm{P}-)$ based on the results obtained by using the bioassays reported earlier $(9,15)$. Four categories of isolates were distinguished: (i) true positives, when a positive TaqMan PCR analysis $(\mathrm{S}+)$ corresponded to a pathogenic isolate $(\mathrm{P}+, \mathrm{S}+)$; (ii) true negatives, when the analysis produced a negative result $\left(\mathrm{S}_{-}\right)$) and the fungal isolate did not cause the disease (P-,S-); (iii) false positives, when the TaqMan PCR identified an isolate as pathogenic but the isolate did not cause the disease $(\mathrm{P}-, \mathrm{S}+)$; and (iv) false negatives, when the TaqMan PCR did not identify an isolate that actually caused the disease in the bioassay $(\mathrm{P}+, \mathrm{S}-)$. For isolates, the true positive proportion (TPP) and the false negative proportion (FNP) were calculated as a measure of the sensitivity and specificity of the TaqMan PCR method, respectively (13). Method accuracy was evaluated by calculating overall accuracy as (true positive + true negative)/total cases, the Jouden's index ( $\mathrm{J}=\mathrm{TPP}-\mathrm{FNP})$, and the likelihood ratios (LR) of successful and wrong detection of a pear-pathogenic isolate: $L R(\mathrm{P}+)=\mathrm{TPP} /$ false positive proportion $(\mathrm{FPP})$ and $L R(\mathrm{P}-)=\mathrm{FNP} /$ true negative proportion $(\mathrm{TNP})$, respectively. To assess the advantages arising from using the molecular markers instead of performing a bioassay, the posterior probabilities that pear-pathogenic and nonpathogenic isolates are correctly detected by TaqMan $\mathrm{PCR}-P(\mathrm{P}+, \mathrm{S}+)$ and $P(\mathrm{P}-, \mathrm{S}-)$, respectively-were determined.

The 72 leaves collected in the pear orchards affected by brown spot (Table 2) were considered affected $(\mathrm{A}+)$ and unaffected $(\mathrm{A}-$ ) based on the presence of disease symptoms visible to the naked eye, regardless of the extent of the leaf blade with symptoms (i.e., disease severity). Results of the TaqMan PCR were considered positive when the analysis detected the presence of a pathogenic isolates in the leaf $(\mathrm{S}+)$, regardless of the amounts of DNA quantified; the test was considered negative when it did not show the DNA of a pathogenic isolate $(\mathrm{S}-)$. Cases were then distinguished in (i) correct visual diagnosis of infection $(\mathrm{A}+, \mathrm{S}+)$, (ii) correct visual diagnosis of noninfection $(\mathrm{A}-, \mathrm{S}-)$, (iii) wrong visual diagnosis of infection $(\mathrm{A}+, \mathrm{S}-)$, and (iv) wrong visual diagnosis of noninfection $(\mathrm{A}-, \mathrm{S}+)$. All of these possible combinations were organized in a two-by-two contingency table, and the relationships between groups were analyzed using a $\chi^{2}$ test using the Yates correction for continuity and the Kappa coefficient of Cohen using SPSS (ver. 15.0, SPSS Inc., Chicago). The Kappa coefficient is a measure of agreement between two estimators (i.e., visual assessment and TaqMan PCR) when both estimators are used to measure the same thing (i.e., the same leaves). It measures the percentage of data values in the main diagonal of the contingency table and then adjusts these values for the amount of agreement that could be expected due to chance alone: a value of 1 implies perfect agreement and values $<1$ imply less than perfect agreement (10).

\section{RESULTS}

Development of the TaqMan PCR. AFLP analyses using a series of different primer combinations were performed on three isolates pathogenic on pear and fingerprints were compared with the profiles obtained with pools of isolates $(n=4)$ either nonpathogenic on pear but originating from pear orchards, or from asparagus, or from onion. The fingerprints of pear-pathogenic isolates consistently diverged from those of nonpathogenic isolates or asparagus or onion isolates. A typical example of the DNA profiles obtained is shown in Figure 1 for primer combination $E c o$ RI +A - MseI +ATC, where all three pear-pathogenic isolates shared fragments that were absent in any of the pools.

Using 16 primer combinations, many polymorphic fragments were identified and 48 of them were excised from gel, reamplified using the corresponding AFLP primers, and analyzed on agarose gel. Twelve candidate fragments were rejected because multiple bands were present in the amplification mix or amplicons were too small. The remaining 36 bands were sequenced and led to six fragments with a high-quality double-stranded sequence of sufficient length for the design of primers and probe. These primers were subsequently tested in PCR reactions with isolates from the different pathogenicity categories. Primers corresponding to four fragments gave a response with both pathogenic and nonpathogenic isolates and were discarded. Primers designed on two remaining fragments showed a strong signal with all pathogenic isolates, whereas no signal was obtained with any of the tested nonpathogens. Primer and probe combinations from these loci were subsequently tested in TaqMan PCR reactions. Using 1 to $3 \mathrm{ng}$ of fungal DNA, pathogenic isolates showed large variation for one locus with $C_{t}$ values of 19 and 21 for most isolates but $C_{t}$ values $\approx 30$ for some others. In addition, whereas most nonpathogens did not react, five isolates within this category showed $\mathrm{C}_{\mathrm{t}}$ values of 35 to 38 . Results with the other locus were clear cut because pathogenic isolates showed $C_{t}$ values of $\approx 23$ whereas nonpathogens gave $C_{t}$ values $>39.5$. Hence, all subsequent analyses were performed with the oligonucleotides derived from this locus: forward primer 5' TCTCATCGGAGGCAGTGATG 3', reverse primer 5' TGGAGATATCACGGAAAATGAGTTC 3' (Eurogentec), and a TaqMan probe 5' CTTGACATAGGCTGGTAAATGGGTCT 3', labeled at the 5'end with 6-FAM and at the $3^{\prime}$ end with an Eclips Dark Quencher (Eurogentec, Belgium). Calibration curves (obtained for $S$. vesicarium isolate PRI933; slope $=-3.26 ; R^{2}>0.99$ ) had a dynamic range between $1 \mathrm{ng}$ and $100 \mathrm{fg}$ of $S$. vesicarium DNA.

Evaluation of the TaqMan PCR. The capability of the TaqMan PCR to distinguish pear-pathogenic isolates from nonpathogenic isolates of $S$. vesicarium was tested using an independent set of isolates (Table 1). With the purpose of performing

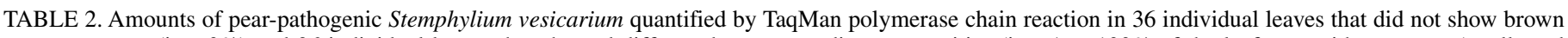

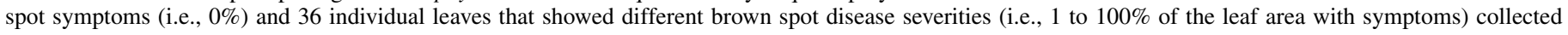
from six different orchards

\begin{tabular}{|c|c|c|c|c|c|c|c|}
\hline \multirow[b]{2}{*}{ Place $^{\mathrm{a}}$} & \multirow[b]{2}{*}{ Location } & \multirow[b]{2}{*}{ Cultivar } & \multicolumn{5}{|c|}{ DNA of pear-pathogenic $S$. vesicarium (pg mg ${ }^{-1}$ leaf dry weight) for each disease severity ${ }^{b}$} \\
\hline & & & $0 \%$ & 1 to $<25 \%$ & 25 to $50 \%$ & $>50$ to $75 \%$ & $>75$ to $100 \%$ \\
\hline Randwijk, NL & $51^{\circ} 57^{\prime} \mathrm{N} / 5^{\circ} 43^{\prime} \mathrm{E}$ & Conference & $0(6)$ & $37(4)$ & - & $6.0(1)$ & $0(1)$ \\
\hline Ravenna, IT & $44^{\circ} 24^{\prime} \mathrm{N} / 12^{\circ} 11^{\prime} \mathrm{E}$ & Abate & $0(6)$ & - & $255(6)$ & - & - \\
\hline Coccanile, IT & $44^{\circ} 55^{\prime} \mathrm{N} / 11^{\circ} 52^{\prime} \mathrm{E}$ & Abate & $1.5(6)$ & $2.0(4)$ & $18(2)$ & - & - \\
\hline Casumaro, IT & $44^{\circ} 55^{\prime} \mathrm{N} / 11^{\circ} 21^{\prime} \mathrm{E}$ & Abate & $0.5(6)$ & $16(2)$ & $192(2)$ & $122(2)$ & - \\
\hline Copparo, IT & $44^{\circ} 58^{\prime} \mathrm{N} / 11^{\circ} 44^{\prime} \mathrm{E}$ & Abate & $0(6)$ & $47(2)$ & $0(1)$ & 237 (1) & $770(2)$ \\
\hline Girona, SP & $41^{\circ} 54^{\prime} \mathrm{N} / 2^{\circ} 49^{\prime} \mathrm{E}$ & Passe crassane & $1.7(6)$ & $0.6(5)$ & $0(1)$ & - & - \\
\hline Total & $\ldots$ & $\ldots$ & $0.5(36)$ & $17(17)$ & $163(12)$ & $122(4)$ & $513(3)$ \\
\hline
\end{tabular}

a NL, The Netherlands; IT, Italy; and ES, Spain.

b Mean values of DNA, number of leaves in parentheses; disease severity determined by visual assessment; - = no observation. 
a conservative evaluation, isolates 440 el93, 369\00, and 424/93, which showed slight disease symptoms in the bioassay, were considered $\mathrm{P}-$. The results of the TaqMan PCR were considered positive when the analysis identified a pathogenic isolates of $S$. vesicarium $(\mathrm{S}+)$ and negative when the analysis did not $(\mathrm{S}-)$. For the sake of caution, the isolate PCF-KOG 315 was considered Sbecause it showed a much weaker signal than all the other isolates.

The method showed high sensitivity and specificity, with TPP being 0.98 and TNP $=0.82$ (Table 3 ). Overall accuracy was 0.93 and $\mathbf{J}=0.80$. There was only one false-negative detection (resulting in an FNP =0.03): the isolate PCF-KOG 315, originating from a pear fruit showing an atypical nose-rot symptom, was pathogenic in the bioassay but the TaqMan PCR showed a $C_{t}$

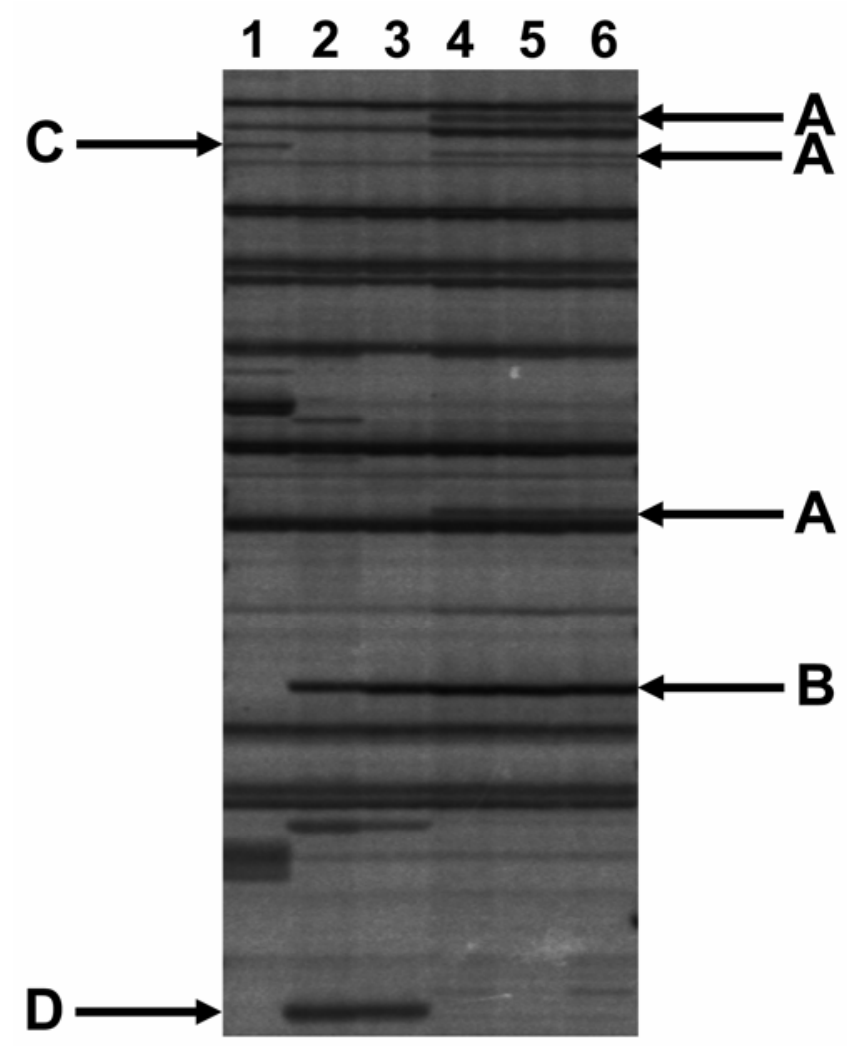

Fig. 1. Example of an amplified fragment length polymorphism fingerprint showing shared and population specific fragments. Lane $1=$ pool of four isolates from asparagus; lane $2=$ pool of four isolates from onion; lane $3=$ pool of four nonpathogenic isolates from pear (fruit or leaves); and lanes 4, 5, and $6=$ pear-pathogenic isolates PRI 875, PRI 933, and PRI 854, respectively. Arrows indicated by A represent fragments present in pear-pathogenic isolates but absent in any of the pools of non-pear pathogens; B depicts a fragment shared by all pear-pathogenic isolates and one or more isolates nonpathogenic in pear from pear or from onion but missing in all four asparagus isolates, while $\mathrm{C}$ represents a fragment present in one or more asparagus isolates but missing in any of the other categories. Fragment D symbolizes fragments found in isolates from onion and pear (nonpathogenic). value of 13 values higher than for the other pathogenic isolates. The three false-positive detections (resulting in FPP $=0.18$ ) were due to the fact that isolates 440 el93, 369100, and 424/93 were cautiously considered nonpathogenic, even though they showed few symptoms under the very conducive conditions of the bioassay (15). When these isolates were considered to be pear pathogenic, sensitivity did not change greatly but specificity increased to $\mathrm{TNP}=1$, and both overall accuracy and $\mathrm{J}$ were 0.98 .

The probability of correctly detecting a $S$. vesicarium isolate as pathogenic using TaqMan $\mathrm{PCR}$ was $P(\mathrm{P}+, \mathrm{S}+)=0.93$, and the probability of correctly detecting a nonpathogenic isolate was $P\left(\mathrm{P}-, \mathrm{S}_{-}\right)=0.94$ (which increased to 1.00 in the case of the three isolates causing slight symptoms were considered to be pear pathogenic). The posterior probability that a nonpathogenic isolate was considered pathogenic based on the PCR analysis was $P(\mathrm{P}-, \mathrm{S}+)=$ 0.06 , and the posterior probability that a pathogenic isolate was not detected as pathogenic was $P(\mathrm{P}+, \mathrm{S}-)=0.07$ (which decreased to zero in the case of the three above-mentioned isolates being considered pear pathogenic) (Table 3).

Disease symptoms and TaqMan PCR on individual leaves. In 12 of the 36 leaves which were considered affected by brown spot, the TaqMan PCR did not detect pear-pathogenic $S$. vesicarium. This failure to detect $S$. vesicarium occurred for two leaves collected in Randwijk, four leaves in Coccanile, one leaf in Copparo, and five leaves in Girona; disease severity of these leaves ranged from low to high (data not shown). In 3 disease-free leaves collected at Coccanile, Casumaro, and Girona, the TaqMan PCR detected minute amounts of DNA belonging to pearpathogenic isolates whereas, in all of the 33 remaining diseasefree leaves, no DNA of pathogenic isolates was detected (Tables 2 and 4). Observed proportions for leaves with correct diagnosis based on disease symptoms were 0.33 for $\mathrm{A}+, \mathrm{S}+$ (presence of both symptoms and DNA of pathogenic isolates) and 0.46 for A-,S- (absence of both symptoms and DNA of pathogenic isolates), whereas proportions for wrong diagnosis were 0.04 for $\mathrm{A}+, \mathrm{S}-$ (presence of symptoms with no fungal DNA) and 0.17 for $\mathrm{A}-, \mathrm{S}+$ (no symptoms but presence of DNA of pathogenic isolates) (Table 4).

The $\chi^{2}$ test applied to the correspondent two-by-two contingency table showed a significant association between diagnosis based on disease symptoms and TaqMan PCR $(P<0.0001)$, but the Kappa coefficient was 0.583 (95\% confidence interval of 0.384 to 0.689 ) (Table 4 ), which is only a moderate agreement (1). Considering the performances obtained by the TaqMan PCR by using artificial inoculation of $S$. vesicarium under optimal conditions for infection and symptom development (bioassay), this result may be attributed to failure in correctly detecting the diseased leaves by the naked eye rather than in a reduced reliability of the molecular tool. In fact, when no DNA is present on a leaf with brown-spot-like symptoms, the symptoms may be caused by other pathogens or abiotic stress and the visual diagnosis should be considered incorrect. Otherwise, when DNA is detected in a leaf with no symptoms visible by the naked eye, epiphytic inoculum of pear-pathogenic $S$. vesicarium on the leaf or latent infections may be present.

TABLE 3. Comparison between detection of pear-pathogenic isolates of Stemphylium vesicarium by bioassays and by TaqMan polymerase chain reaction (PCR)

\begin{tabular}{|c|c|c|c|c|c|c|}
\hline \multirow[b]{2}{*}{ Bioassay } & \multicolumn{2}{|c|}{ TaqMan PCR ${ }^{\mathrm{a}}$} & \multirow[b]{2}{*}{ Total } & \multirow[b]{2}{*}{ Accuracy } & \multirow[b]{2}{*}{ Likelihood ratio $(L R)$} & \multirow[b]{2}{*}{ Posterior probability $(P)$} \\
\hline & Yes $(\mathrm{S}+)$ & No $\left(\mathrm{S}_{-}\right)$ & & & & \\
\hline Pathogenic (P+) & $39 \mathrm{TPP}=0.98$ & $1 \mathrm{FNP}=0.03^{\mathrm{b}}$ & 40 & $0.93^{c}$ & $L R(\mathrm{P}+)=5.5$ & $P(\mathrm{P}+, \mathrm{S}+)=0.93, P(\mathrm{P}+, \mathrm{S}-)=0.07$ \\
\hline Nonpathogenic $(\mathrm{P}-)$ & $3 \mathrm{FPP}=0.18^{\mathrm{d}}$ & $14 \mathrm{TNP}=0.82$ & 17 & $0.80^{\mathrm{e}}$ & $L R(\mathrm{P}-)=0.03$ & $P(\mathrm{P}-, \mathrm{S}+)=0.06, P(\mathrm{P}-, \mathrm{S}-)=0.94$ \\
\hline Total & 42 & 15 & 57 & $\ldots$ & $\ldots$ & $\ldots$ \\
\hline
\end{tabular}

a $\mathrm{TPP}=$ true positive proportion (sensitivity), FNP = false negative proportion, FPP = false positive proportion, and TNP true negative proportion (specificity).

${ }^{\mathrm{b}}$ Isolate PCF-KOG 315, which had a TaqMan PCR signal much weaker than all the other isolates, was conservatively considered S-.

c Overall accuracy: $(39+23) / 66$.

$\mathrm{d}$ Three isolates (440 el93, 424\93, and 369\00), which showed low disease incidence in the bioassay, were conservatively considered P-.

e Jouden's index (J): TPP - FPP. 
Quantities of necrotic plant tissues and their colonization by $S$. vesicarium in orchards. The quantities of necrotic plant tissues present on the orchard floors over time differed per type of tissue (Fig. 2). The amount of necrotic pear leaves increased during October and November but decreased steadily in the subsequent months, although small amounts of pear leaf residues were still present during the summer in both locations. More leaf tissue per surface area was found in the tree strips than in the grass alleys. Only low amounts of necrotic grass leaves were observed during winter but amounts increased during spring. In the grass alleys at both locations, more necrotic grass tissues were present during summer and autumn than dead pear leaf tissues (Fig. 2A and B). In general, higher amounts of necrotic plant tissues were present in the tree strips than in the grass alleys. Plant residues (not being necrotic pear leaves) on the soils of the tree strips, consisting of the remains from pruned twigs, aborted pear fruit, and dead weeds, were consistently present during the entire year at both locations (Fig. 2C and D). These quantities were comparable with those of fallen leaves in Breskens during winter but increased during summer (Fig. 2C), and similar observations were made in Randwijk (Fig. 2D). The amounts of plant debris present in the upper 2-cm soil layer of the tree strips exceeded the amounts of either necrotic leaves or other plant residues on soil at all sampling dates. This difference was more pronounced in Randwijk than in Breskens (Fig. 2C and D).

The amount of DNA of pear-pathogenic $S$. vesicarium was determined in samples collected at monthly intervals between October 2007 and May 2008. Thereafter, samples were analyzed at 2-month intervals. In samples of the various tissue types collected in Randwijk, DNA of pear-pathogenic $S$. vesicarium was found in only five cases, with concentrations of DNA of $S$. vesicarium at 5 to $11 \mathrm{pg} \mathrm{mg}^{-1}$ dry weight. Four of these samples were pear leaf samples from either grass alleys (November 2007 and October 2008) or tree strips (January 2008 and October 2008). The fifth positive sample consisted of grass residues collected in February 2008.

In Breskens, DNA of pear-pathogenic $S$. vesicarium was never found in debris present in the upper 2-cm soil layer, with the exception of one sample, collected in March 2008, which contained DNA of $S$. vesicarium at $11 \mathrm{pg} \mathrm{mg}^{-1}$ dry weight. For residues of the lawn grasses, only two samples were positive (DNA of $S$. vesicarium collected in November 2007 at $27 \mathrm{pg} \mathrm{mg}^{-1}$ dry weight and in February 2008 with 8 pg mg $^{-1}$ dry weight). In contrast to these substrate types, S. vesicarium showed another colonization pattern in samples of pear leaves and plant residues on the soil of tree strips. From leaf fall in autumn 2007 until March 2008, the

TABLE 4. Comparison between diagnosis of brown spot on pear leaves collected in the pear orchards based on the presence of disease symptoms and on the TaqMan polymerase chain reaction (PCR)

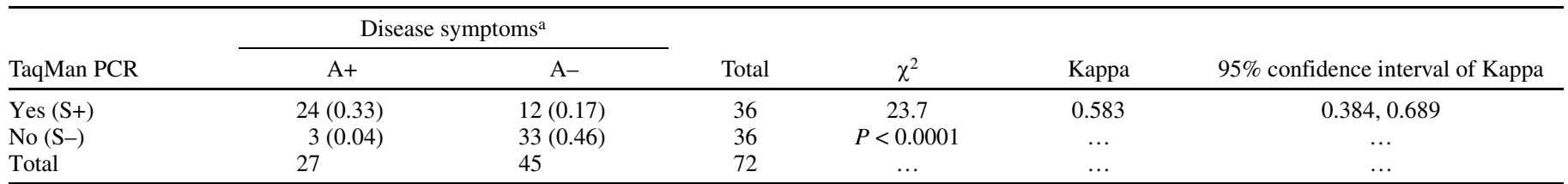

${ }^{a}$ Leaves were considered affected (A+) or unaffected (A-) based on the presence of disease symptoms visible to the naked eye, regardless of the extent of the leaf blade with symptoms. Observed proportions (in parentheses) correct visual diagnosis of infection $(\mathrm{A}+, \mathrm{S}+)$; correct visual diagnosis of noninfection $(\mathrm{A}-, \mathrm{S}-)$; wrong visual diagnosis of infection $(\mathrm{A}+, \mathrm{S}-)$; wrong visual diagnosis of noninfection $(\mathrm{A}-, \mathrm{S}+)$.
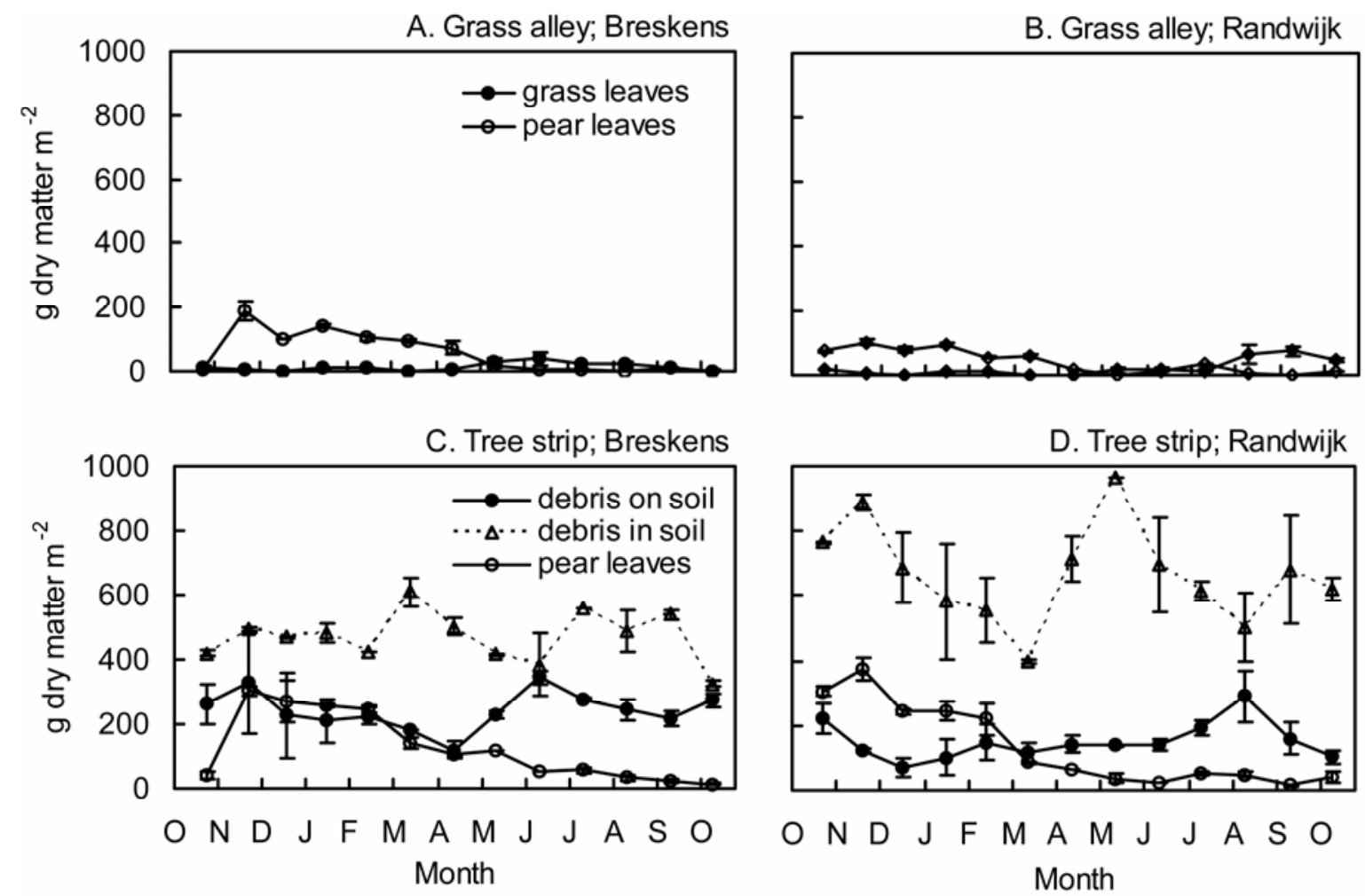

Fig. 2. Amounts of plant residues on the floors of pear orchards in A and C, Breskens and B and D, Randwijk from October 2007 until October 2008 . Debris on soil contained pruned twigs, aborted fruit, and dead weeds. Samples were collected in four random 25 -by-25-cm patches in the grass alleys as well as in the tree strips. Bars indicate the standard error of the mean ( $n=$ two plots $)$. 
majority of the samples was positive, with $S$. vesicarium DNA concentrations of 5 to $860 \mathrm{pg}$ of $\mathrm{mg}^{-1}$ dry weight. Samples obtained from plot 1 (with a higher brown spot incidence in 2007) generally had higher levels of colonization by the pathogen (Fig. 3A and C). However, after March 2008, DNA of the pathogen was no longer detected in samples of either pear leaves or plant residues. Between autumn 2007 and March 2008, the concentration of pathogen DNA decreased exponentially in leaf samples collected in plot 1 (Fig. 3C), whereas levels of colonization varied considerably between sampling dates in plot 2. Similar patterns of pathogen DNA concentration were observed in pear leaves collected from the grass alleys (data not shown).

In tree strips, a maximum of $21.5 \mu \mathrm{g}$ of DNA of pearpathogenic $S$. vesicarium per square meter of orchard floor was found in pear leaves (Fig. 3D). The maximum value for plant residues (other than pear leaves) collected per square meter of orchard floor was $308 \mu \mathrm{g}$ of DNA of pear-pathogenic S. vesicarium (Fig. 3B). However, after a steep decrease in DNA concentration during spring, pathogen DNA was not detected in samples collected in summer, not even in samples from plots with highest values during winter.

\section{DISCUSSION}

A previous study showed that $S$. vesicarium isolates pathogenic on pear, isolates nonpathogenic on pear, or isolates originating from asparagus or onion formed distinct populations with significantly different AFLP patterns (9). In this study, we identified DNA fragments that are specific for pear-pathogenic isolates. The efficiency of the screening for such DNA fragments was highly improved by pooling DNA extracts of nonpathogenic isolates, of which none should contain such fragments. Out of 48 selected specific fragments, 6 fragments containing sufficient sequence information were obtained, so that TaqMan PCR primers and probes were designed. A TaqMan PCR assay was developed for the most suitable set of primers and probe. The dynamic range of the assay for reliable quantitative detection ranged from $1 \mathrm{ng}$ to $100 \mathrm{fg}$ of DNA. The developed TaqMan PCR had high sensitivity, specificity, and accuracy. It detected pear-pathogenic isolates of $S$. vesicarium originating from four different European countries and
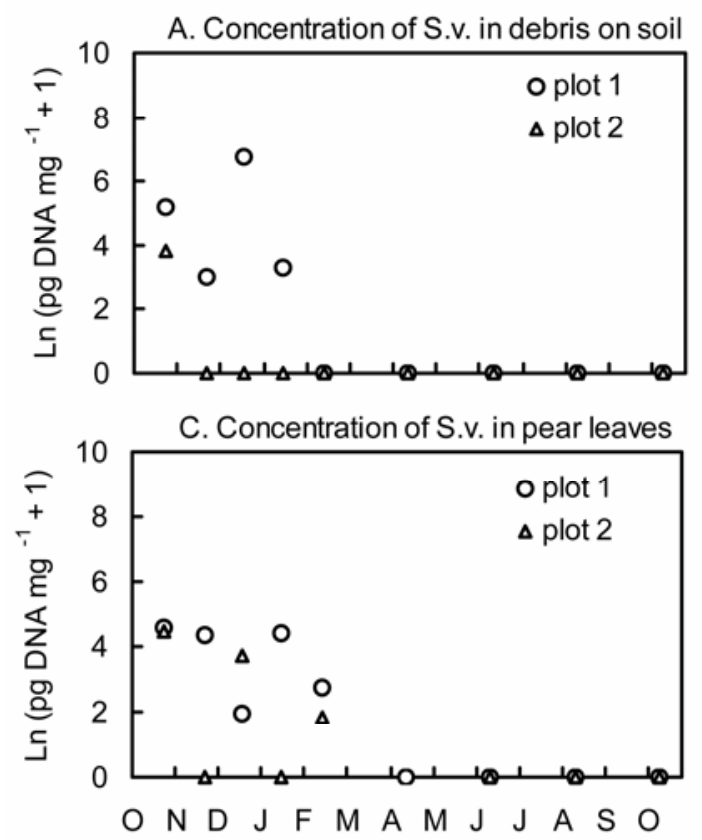

various regions within those countries. The only exception found so far was isolate PCF-KOG 315, originally isolated from a pear fruit with nose rot as a symptom atypical for brown spot, which potentially can cause brown-spot symptoms in bioassays (9). No cross-reaction was found with nonpathogenic isolates of $S$. vesicarium or isolates belonging to other Stemphylium or Alternaria spp. The function of the selected DNA fragment is unknown. BLAST analysis showed no similarity with any published sequence. The DNA fragment may be part of an unknown gene coding for a pathogenicity factor specific for pear or may circumstantially be positioned close to such a gene. Thus, further research on the identified DNA fragment is needed to elucidate its function. With a similar approach, specific TaqMan PCR could also be developed for $S$. vesicarium pathogenic to other hosts (e.g., to onion or asparagus) based on AFLP patterns showing specific DNA fragments (Fig. 1).

The pathogen was detected on pear leaves showing brown-spot symptoms originating from six different locations in The Netherlands, Italy, and Spain. Only minute amounts of pear-pathogenic $S$. vesicarium were found on 3 of 36 symptom-free leaves collected in infected orchards. Likely, the pathogen was present on these symptom-free leaves as an epiphyte or latent within the leaf tissue. On the other hand, the pathogen was not detected by TaqMan PCR in $30 \%$ of the leaves with symptoms. One explanation of this result is that the pathogen did cause symptoms on those leaves through the formation of toxins (23) but it did not survive in the lesions. This is in line with observations that the pathogen rarely produces conidia on brown-spot lesions (11) and that isolation of the pathogen from lesions is not always successful. More likely, it cannot be excluded that the brown-spot-like symptoms observed on these leaves were incited by other pathogens or by abiotic stress, such as in the so-called 'brusone' in Italy (3). Application of the pathogen-specific TaqMan PCR will help to better understand the expression of brown-spot symptoms and to increase the accuracy of the disease diagnosis.

A limited monitoring of pear-pathogenic $S$. vesicarium populations on crop residues was done in two Dutch orchards. The results confirmed that the developed TaqMan PCR can be applied to environmental samples to obtain quantitative data of pearpathogenic $S$. vesicarium on very different substrate types. Possi-
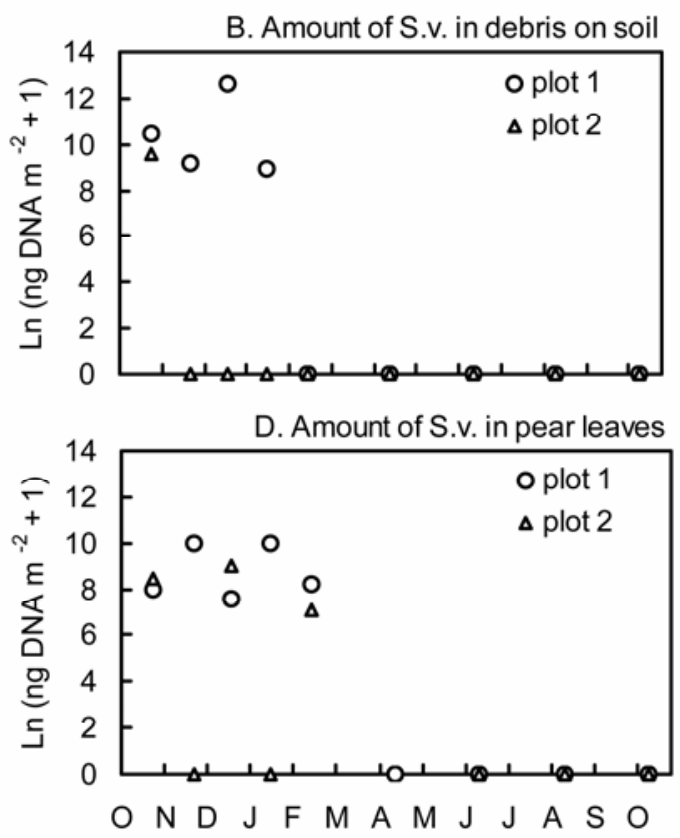

Fig. 3. A and $\mathbf{C}$, Concentration ( $\mathrm{pg} \mathrm{mg}^{-1}$ dry weight) and $\mathbf{B}$ and $\mathbf{D}$, amount $\left(\mathrm{ng} \mathrm{m}^{-2}\right)$ of DNA of pear-pathogenic Stemphylium vesicarium (S.v.) present in debris (pruned twigs, aborted fruit, and dead weeds but pear leaves excluded) $\mathbf{A}$ and $\mathbf{B}$, on soil and $\mathbf{C}$ and $\mathbf{D}$, in pear leaves sampled from the orchard floor in the tree strips of two replicate plots in Breskens, from October 2007 until October 2008. 
ble inhibition of amplification was observed in few cases. If our AC indicated such inhibition, dilution of the DNA extracts allowed reliable measurements without inhibition. Measurements showed an unexpected high variation between sampling dates (e.g., for leaves on the soil in plot 2 in Breskens) (Fig. 3C). This may be due to an irregular distribution of the fungal population on the orchard floor. In this case, sampling strategies must be improved (e.g., the number of subsamples must be increased). However, the populations may also fluctuate rapidly due to environmental conditions. This aspect should be evaluated in future studies.

Brown spot had been observed in both orchards at the end of the growing season of 2007. The disease incidence on fruit was $<1 \%$ in Randwijk and $\approx 25 \%$ in Breskens. After the growing season of 2007, pear-pathogenic $S$. vesicarium was detected by TaqMan PCR in Randwijk in only a few cases. In Breskens, a pathogenic population was established in pear leaves and other crop residues after the growing season of 2007. Larger populations were found in samples from the orchard area in which more disease was present in 2007 (Fig. 3, plot 1). The population was almost constant during winter but, from the beginning of the growing season in 2008 onward, the pathogen population was not detected any longer. The reasons for this result are not known. Different fungicides were regularly applied at 24 dates from late February to early September 2008, most of them being effective against brown spot (11). These fungicides were applied to the tree canopy; therefore, their real impact on the fungal population of the orchard floor remains to be investigated. A decrease of the pathogen population in plant debris may also be caused by specific environmental conditions or naturally occurring competing antagonists, including nonpathogenic populations of $S$. vesicarium. Such a potential antagonism should be investigated to develop new agents for biological control of brown spot (12).

The brown spot incidence at harvest in 2008 was only $0.6 \%$ on fruit in Breskens, and no fruit were affected in Randwijk. This is in agreement with a population of pear-pathogenic $S$. vesicarium below the detection level of the TaqMan PCR during the usual period of epidemic development. The obtained first insight in the overwintering of pear-pathogenic populations $S$. vesicarium in crop residues indicated that fallen pear leaves and other plant residues present on the orchard floor within the tree strip harbored the major part of the pathogen population and a smaller part was found in the grass alleys. During autumn and winter, when the highest values were recorded, many residues of pruned twigs were present in tree strips. This finding strongly suggests the need for more detailed observations in different years and locations on colonization of plant residues by $S$. vesicarium, with special focus on twigs before and after pruning.

The developed TaqMan PCR for pear-pathogenic populations of $S$. vesicarium in environmental samples will allow detailed studies of brown-spot epidemiology. The niches for survival and the sources for inoculum production of the pathogen can be identified as well as the relative importance of different inoculum sources such as fallen pear leaves (12) and herb plants of orchard lawns (20). Furthermore, conidia and ascospores can reliably be distinguished from those of nonpathogenic $S$. vesicarium or other Stemphylium spp. Data on spore flights of pear-pathogenic $S$. vesicarium are essential for further improvement of disease-forecasting models $(6,18)$. Also, disease assessments on leaves and fruit can now be combined with quantification of the pathogen in the lesion tissue, and lesions caused by $S$. vesicarium can better be distinguished from lesions caused by other pathogens or by environmental stresses. Another potential application of the TaqMan PCR is the monitoring of pathogen populations in pear orchards at the beginning of the growing season. In The Netherlands, brown spot often does not develop even in orchards which had been severely affected during the preceding growing season, as also occurred in the two orchards sampled during this study. As long as growers envisage the potential risk of damage by brown spot, growers tend to use preventive spray schedules with specific fungicides against brown spot. If the absence of pear-pathogenic $S$. vesicarium can be confirmed by using TaqMan PCR on appropriate samples of potential inoculum sources, such unnecessary preventative spray schedules can be avoided in the future.

\section{ACKNOWLEDGEMENTS}

This study was funded by the Dutch Ministry of Agriculture, Nature and Food quality. We thank I. Llorente, Institute of Food and Agricultural Technology, University of Girona, Spain; P. Creemers, Pcfruit, Gorsem, Belgium; and P.-F. de Jong, Applied Plant Research (PPO-Fruit), Zetten, The Netherlands, for providing isolates of $S$. vesicarium, leaf samples, and disease ratings. A. M. Manneke, fruit grower in Breskens, and PPOFruit provided field plots and $\mathrm{H}$. van Raaij (PRI) performed part of the AFLP experiments.

\section{LITERATURE CITED}

1. Altman, D. G. 1991. Practical Statistics for Medical Research. Chapman and Hall, London.

2. Aveling, T. A. S., and Snyman, H. G. 1993. Infection studies of Stemphylium vesicarium on onion leaves. Mycol. Res. 97:984-988.

3. Bonany, J., Villardell, P., Camps, F., and Lasko, A. N. 1991. Le cause del "brusone" nel pero cv. 'Conference'. Frutticoltura 53(11):65-69.

4. de Jong, P. F., and Heijne, B. 2008. Exclusion of the inoculum source of brown spot (Stemphylium vesicarium). Acta Hortic. (ISHS) 800:833-838.

5. Falloon, P. G., Falloon, L. M., and Grogan, R. G. 1987. Etiology and epidemiology of Stemphylium leaf spot and purple spot of asparagus in California. Phytopathology 77:407-413.

6. Giosuè, S., Rossi, V., Bugiani, R., and Mazzoni, C. 2006. Modelling dynamics of airborne conidia of Stemphylium vesicarium, the causal agent of brown spot of pear. IOBC/WPRS Bull. 29(1):169-176.

7. Hudson, H. J. 1971. The development of the saprophytic fungal flora as leaves senesce and fall. Pages 447-455 in: Ecology of Leaf Surface Micro-Organisms. T. F. Preece and C. H. Dickinson, eds. Academic Press, London and New York.

8. Klerks, M. M., Zijlstra, C., and Van Bruggen, A. H. C. 2004. Comparison of real-time PCR methods for detection of Salmonella enterica and Escherichia coli $\mathrm{O} 157: \mathrm{H7}$, and introduction of a general internal amplification control. J. Microbiol. Methods 59:337-349.

9. Köhl, J., Molhoek, W. M. L., Groenenboom-de Haas, B. H., Goossen-van de Geijn, H. M., Speksnijder, A., Kastelein, P., de Hoog, S., and Gerrits van der Ende, A. H. A. 2009. Pathogenicity of Stemphylium vesicarium from different hosts causing brown spot in pear. Eur. J. Plant Pathol. 124:151-162.

10. Liebetrau, A. M. 1983. Measures of association. In: Quantitative Applications in the Social Sciences Series No. 32. Sage Publications, Newbury Park, CA.

11. Llorente, I., and Montesinos, E. 2006. Brown spot of pear: An emerging disease of economic importance in Europe. Plant Dis. 90:1368-1375.

12. Llorente, I., Vilardell, A., and Montesinos, E. 2006. Infection potential of Pleospora allii and evaluation of methods for reduction of the overwintering inoculum of brown spot of pear. Plant Dis. 90:1511-1516.

13. Madden, L. V. 2006. Botanical epidemiology: Some key advances and its continuing role in disease management. Eur. J. Plant Pathol. 115:3-23.

14. Pattori, E., Cavagna, S., Righi, K., and Rossi, V. 2007. Effect of Trichoderma sp. on sporulation of Stemphylium vesicarium, the causal agent of pear brown spot. J. Plant Pathol. 89(3, Suppl.):S53.

15. Pattori, E., Rossi, V., Bugiani, R., and Giosuè, S. 2006. Virulence of Stemphylium vesicarium isolates from pear and other host species. IOBC/WPRS Bull. 29(1):195-205.

16. Polfliet, M. 2002. Aantasting Stemphylium neemt met het jaar toe [Infection of Stemphylium increases every year]. Fruitteelt 92(20):16-17.

17. Ponti, I., Cavanni, P., and Brunelli, A. 1982. Maculatura bruna delle pere: Eziologia e difesa. Informatore Fitopatologico 32:35-40.

18. Rossi, V., Bugiani, R., Giosuè, S., and Natali, P. 2005. Patterns of airborne conidia of Stemphylium vesicarium, the causal agent of brown spot disease of pears, in relation to weather conditions. Aerobiologia 21:203216.

19. Rossi, V., Pattori, E., and Bugiani, R. 2008. Sources and seasonal dynamics of inoculum for brown spot disease of pear. Eur. J. Plant Pathol. 121:147-159.

20. Rossi, V., Pattori, E., Giosuè, S., and Bugiani, R. 2005. Growth and sporulation of Stemphylium vesicarium, the causal agent of brown spot of pear, on herb plants of orchard lawns. Eur. J. Plant Pathol. 111:361-370. 
21. Simmons, E. G. 1969. Perfect stages of Stemphylium. Mycologia 61:1-26.

22. Simmons, E. G. 1995. Alternaria themes and variations (112-144). Mycotaxon 55:55-163.

23. Singh, P., Bugiani, R., Cavanni, P., Nakajima, H., Kodama, M., Otani, H., and Kohmoto, K. 1999. Purification and biological characterization of host-specific SV-toxins from Stemphylium vesicarium causing brown spot of European pear. Phytopathology 89:947-953.

24. Smucker, A. J. M., McBurney, S. L., and Srivastava, A. K. 1982. Quantitative separation of roots from compacted soil profiles by the hydropneumatic elutriation system. Agron. J. 74:500-503.

25. Yven, J. E., and Hughes, G. 2002. Bayesian analysis of plant disease prediction. Plant Pathol. 51:407-412. 